\title{
Absensi dan Kartu Parkir Mahasiswa Menggunakan Kartu Radio Frequency Identification Dengan Bahasa Pemrograman Visual Basic
}

\author{
Sigit Mintoro ${ }^{1}$,Teknik komputer ${ }^{2}$ \\ STMIK Dian Cipta Cendikia Kotabumi \\ Email: 1 sigit@dcc.ac.id, sigitmintoro76@gmail.com
}

\begin{abstract}
ABSTRAK
Sistem Teknologi RFID (Radio-Frequency Identification) saat ini diharapkan dapat mempermudah dan mempercepat mengindentifikasi data dalam perkejaan . Dalam sistem absensi dan parkir ini menggunakan RFID untuk membantu dalam sistem identifikasi , serta membantu dalam merekap data kehadiran mahasiswa serta menjaga keamanan dari tindak kejahatan yang sering terjadi pada saat sekarang ini. Teknologi pada sistem RFId dengan control dari arduino merupakan prospek untuk berbagai kebutuhan, salah satunya untuk sistem absensi dan kartu parkir kendaraan dilingkungan kampus dengan media kartu mahasiswa (KTM) . Dengan adanya penggunaan RFID , diharapkan dapat membuat sistem absensi dan parkir yang ada di saat ini dapat berjalan lebih baik, aman dan nyaman.
\end{abstract}

Kata Kunci : Absensi, Kartu Parkir, RFID, Arduino, Database, VB. 


\section{PENDAHULUAN}

Perkembangan pengetahuan dan Teknologi digital dalam mendukung proses pekerjaan saat ini dengan menggunakan bantuan komputer dalam kegiatan operasional. Dalam meningkatkan efisiensi tenaga dan waktu dan semakin majunya perkembangan teknologi digital zaman di era globalisasi sekarang ini semakin cepat memasuki di berbagai bidang, maka dengan itu pula semakin canggihnya sistim dan hal untuk mengindentifikasi kehadiran dan kriminal dalam melakukan aksinya. Tempat parkir merupakan kebutuhan mutlak bagi pemilik gedung perkantoran, banyak petugas keamanan pun masih belum efektif untuk mengurangi tindak kriminal tersebut. Problem perparkiran kadang merupakan hal yang sangat sulit untuk di cari solusinya agar dapat memberikan keamanan dan kenyamanan bagi pengemudi kendaraan.

Teknologi sistem absensi dan parkir yang berkembang pada saat ini sudah cukup maju namun sistem parkir yang masih digunakan sekarang ini sebagian besar menggunakan sistem manual dan harganya cukup mahal, dalam system ini, bahwa jika mahasiswa dan kendaraan akan memasuki ruangan perkuliahan dan area parkir, dapat masuk apabila menempelkan kartu mahasiswa yang terdaftar dapat masuk ataupun keluar ruangan dan areal parkir tanpa harus absensi manual ataupun memperlihatkan STNK untuk pengecekkan plat nomor kendaraan tersebut. Pada saat ini system keamanan dengan kamera CCTV yang berguna hanya untuk memantau keadaan tersebut. Dari citra yang dihasilkan oleh CCTV dapat diproses lebih lanjut menjadi sistem yang dapat mendeteksi serta menginformasikan posisi kendaraan dan mengenal wajah yang berfungsi untuk memudah pengecekkan apabila terjadi kehilagan kendaraan tersebut di ambil oleh orang yang sama sekali tidak memiliki hak terhadap kendaraan tersebut. Sistem parkir manual saat ini kurang aman dan efisien. Sistem tersebut dinilai masih belum efektif dari segi keamanan dan kenyamanan. Maka dilakukan perancangan suatu sistem absensi dan kartu parker mahasiswa menggunakan kartu Radio Frekuensi Identifikasi (RFID), Pada pintu masuk diberi portal dimana portal akan terbuka melalui kartu RFID sehingga tidak sembarang orang dapat masuk atau keluar dari ruangan ataupun area parkir. Keuntungan menggunakan sistem ini adalah hanya mahasiswa atau yang memiliki akses yang sudah terdata di data base. Dalam penelitian ini juga menggunakan sistem yang terdiri dari 4 bagian utama yaitu Arduino, RFID, Motor Servo dan LCD. Reader akan diletakkan di pintu masuk ruanagan dan pintu masuk area parkir yang berfungsi sebagai pembaca identitas, dimana kartu pengenal tersebut telah diinput dalam database yang telah dirancang. Maka reader akan membaca identitas mahasiswa dan pemilik kendaraan tersebut, apabila identitas tersebut cocok dengan inputan yang ada di database maka identitas akan tampil di LCD dan secara otomatis pintu/portal akan terbuka. Dalam pembuatan sistem absensi dan parkir otomatis ini, terdapat beberapa teori dasar yang meliputi komponen utama alat dan software-nya. Komponen utama dari alat ini terdiri dari Arduino Mega, sensor ultrasonik, LCD, RFID serta software-nya berupa pemograman Arduino Mega.

\section{Dari latar belakang diatas, rumusan masalah yang akan dibahas :}

1. Merancang sistem absensi dan parkir mahasiswa yang berbasis RFID. RFID adalah "Radio Frequency Identification".

2. Membahas cara kerja sistem, langkah langkah, tahapan dan cara 
mentransmisikan data dari RFID menuju ke database.

Tujuan ini adalah untuk mempermudah suatu pekerjaan dalam perusahaan, tujuannya adalah sebagai berikut :

1. Menyusun suatu sistem yang berbasis komputer secara sistematis.

2. Digunakan untuk mengefektifkan absensi kehadiran mahasiswa dan keamanan untuk mengurangi tindakan kriminal di area gedung parkir.

3. Dengan adanya kartu RFID tidak sembarang orang masuklkeluar dari ruangan perkuliahan dan areal parkir.

Manfaat dari membuat sistem absensi dan parkir berbasis RFID, manfaatnya adalah :

1. Menggunakan kartu RFID untuk membantu petugas absensi dan mengefektifkan system keamanan parkir di lingkup kampus.

2. Dan sistem parkir menggunakan RFID dapat mengurangi tindak kriminal di areal parkir.

Dalam penyusunan batasan atau ruang lingkup ini adalah :

1. Sistem yang dibangun hanya terletak di pintu masuk ruang perkuliahan dan areal parkir.

2. Sistem yang dibangun menggunakan VB. sebagai pembuatan software perangkat, dan menggunakan Microsoft Acces. Arduino merupakan rangkaian elektronik yang bersifat open source, serta memiliki perangkat keras dan lunak yang mudah untuk digunakan.

Arduino dapat mengenali lingkungan sekitarnya melalui berbagai jenis sensor dan dapat mengendalikan lampu, motor, dan berbagai jenis aktuator lainnya. Arduino mempunyai banyak jenis, di antaranya Arduino Uno, Arduino Mega 2560, Arduino Fio, dan lainnya. Arduino adalah sebuah board mikrokontroller yang berbasis ATmega328. Arduino memiliki 14 pin input/output yang mana 6 pin dapat digunakan sebagai output PWM, 6 analog input, crystal osilator $16 \mathrm{MHz}$, koneksi USB, jack power, kepala ICSP, dan tombol reset. Arduino mampu men-support mikrokontroller; dapat dikoneksikan dengan komputer menggunakan kabel USB . Setiap 14 pin digital pada arduino dapat digunakan sebagai input atau output, menggunakan fungsi pinMode(), digitalWrite(), dan digitalRead(). Input/output dioperasikan pada 5 volt. Setiap pin dapat menghasilkan atau menerima maximum $40 \mathrm{~mA}$ dan memiliki internal pull-up resistor (disconnected oleh default) 20-50K Ohm. Arduino IDE ( Integrated Development Environment ) adalah perangkat lunak yang digunakan dalam memprogram board arduino. IDE merupakan sebuah perangkat lunak yang memudahkan dalam mengembangkan aplikasi mikrokontroler mulai dari menuliskan source program, kompilasi, meng-upload hasil kompilasi, dan uji coba secara terminal serial. Software arduino IDE bersifat open source, memiliki bahasa pemrograman $\mathrm{C}++$ yang sederhana dan fungsi-fungsinya yang lengkap, sehingga arduino mudah dipelajari oleh pemula.[1] Sensor ultrasonic adalah sensor yang bekerja berdasarkan prinsip pantulan gelombang dimana sensor menghasilkan gelombang pantulan ke benda yang kemudian menangkapnya kembali dengan perbedaan waktu sebagai dasar perhitungannya. Perbedaan waktu antara gelombang pantulan yang di kembalikan dan yang diterima kembali adalah berbanding lurus dengan jarak atau tinggi objek yang memantulkannya. Jenis objek yang dapat di indranya adalah padat, cair dan butiran. Tanpa kontak jarak $2 \mathrm{~cm}$ sampai 3 meter dan 
dapat dengan mudah dihubungkan dengan mikrokontroler malalui satu pin I/O saja. Sensor ini memiliki kemampuan mengubah energy listrik menjadi energy mekanik dalam bentuk gelombang suara ultrasonic. Gelombang ultrasonic adalah gelombang mekanik yang memiliki frekuensi di atas 20 $\mathrm{kHz}$. Gelombang ultrasonic merambat melalui udara dengan kecepatan 340 meter per detik. Dalam bidang kesehatan, gelombang ultrasonik bisa digunakan untuk melihat organ-organ dalam tubuh manusia seperti untuk mendeteksi tumor, liver, otak dan menghancurkan batu ginjal. Gelombang ultrasonik juga dimanfaatkan pada alat USG (ultrasonografi) yang biasa digunakan oleh dokter kandungan.

Dalam bidang industri, gelombang ultrasonik digunakan untuk mendeteksi keretakan pada logam, meratakan campuran besi dan timah, meratakan campuran susu agar homogen, mensterilkan makanan yang diawetkan dalam kaleng, dan membersihkan benda benda yang sangat halus. Gelombang ultrasonik juga bisa digunakan untuk mendeteksi keberadaan mineral maupun minyak bumi yang tersimpan di dalam perut bumi. Dalam bidang pertahanan, gelombang ultrasonik digunakan sebagai radar atau navigasi, di darat maupun di dalam air. Gelombang ultrasonik digunakan oleh kapal pemburu untuk mengetahui keberadaan kapal selam, dipasang pada kapal selam untuk mengetahui keberadaan kapal yang berada di atas permukaan air, mengukur kedalaman palung laut, mendeteksi ranjau, dan menentukan posisi sekelompok ikan.[2] LCD (Liquid Crystal Display) adalah salah satu alat yang digunakan sebagai tampilan. Pada dasarnya sistem pengaturan LCD memiliki standar yang sama walaupun sangat banyak macamnya baik ditinjau dari perusahaan pembuat maupun dari ukurannya. Modul LCD ini telah dilengkapi dengan mikrokontroler yang didesain khusus untuk mengendalikan LCD, berfungsi sebagai pengatur (system controller) dan penghasil karakter (character generator). Keunggulan LCD adalah hanya menarik arus yang kecil ( beberapa mikro ampere ), sehingga alat atau sistem menjadi portable karena dapat menggunakan catu daya yang kecil. Keunggulan lainnya adalah tampilan yang diperlihatkan dapat dibaca dengan mudah dibawah terang sinar matahari. Dibawah sinar cahaya yang remang remang atau dalam kondisi gelap, sebuah lampu ( berupa LED ) harus dipasang dibelakang layar tampilan.[3] RFID dalam bahasa inggris Radio Frequenscy Identification adalah sebuah metode identifikasi dengan menggunakan sarana yang disebut label RFID atau transponder untuk menyimpan dan mengambil data jarak jauh. Laber atau kartu RFID adalah sebuah benda yang bisa dipasang atau dimasukkan didalam sebuah produk, hewan atau bahkan manusia dengan tujuan untuk identifikasi menggunakan lombang radio.[4] Motor Servo adalah sebuah perangkat atau aktuator putar(motor) yang dirancang dengan sistem kontrol umpan balik loop tertutup(servo), sehingga dapat di set-up atau di atur untuk menentukan dan memastikan posisi sudut dari poros output motor. Motor servo merupakan perangkat yang terdiri dari motor DC, serangkaian gear, rangkaian kontrol dan potensiometer. Potensiometer berfungsi untuk menentukan batas sudut dari putaran servo, sedangkan sudut dari sumbu motor servo diatur berdasarkan lebar pulsa yang dikirim melalui kaki sinyal dari kabel motor servo.

Keunggulan dari pengguna motor servo itu sendiri adalah :

1. Daya yang dihasilkan sebanding dengan ukuran dan berat motor

2. Resolusi dan akurasi dapat diubah dengan hanya mengganti encoder yang dipakai 
3. Tidak berisik saat beroperasi dengan kecepatan tinggi Motor servo dapat dimanfaatkan pada pembuatan robot salah satunya sebagai penggerak kaki robot.

Motor servo dipilih sebagai penggerak pada kaki robot karena motor servo memiliki tenaga yang besar, sehingga dapat menggerakkan kaki robot dengan beban yang cukup berat. Pada umumnya motor servo yang digunakan sebagai penggerak pada robot adalah motor servo 180 derajat.[5]

\section{PERANCANGAN SISTEM}

Analisis sistem merupakan penguraian suatu masalah kedalam bagian dari komponenkomponen yang bertujuan untuk mengidentifikasi dan mengevaluasi permasalahan-permasalahan tersebut. Diagram blok adalah diagram dari sebuah sistem, dimana bagian utama atau fungsi yang diwakili oleh blok yang dihubungkan dengan garis, yang menunjukkan hubungan dari blok.

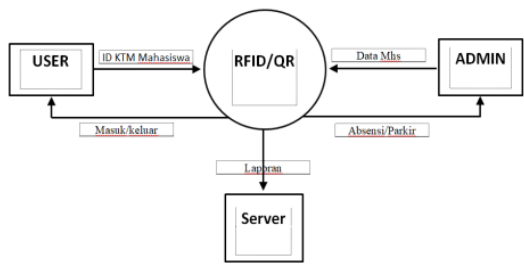

\section{Gambar 1 Diagram Blok Sistem}

Pada blok diagram pada gambar 3.1 Rfid Reader akan membaca kartu RFID, setelah ada kecocokan data maka visual basic akan mencocokan data rfid dengan data database, jika cocok arduino akan memerintahkan motor servo untuk membuka portal dan segera kendaraan bisa memasuki lahan parkir. Seiring kendaraan masuk sensor ultrasonic akan mendeteksi adanya benda yang melewati sensor dengan mengirim gelombang dan menerima gelombang yang dipantulkan benda. Jika terdeteksi maka akan dikirim datanya ke Arduino Uno. Dan kembali memerintahkan motor servo untuk menutup kembali portal parkir. Flowchart sistem merupakan keterangan yang lebih rinci tentang bagaimana langkah-langkah sesungguhnya yang dilakukan oleh suatu sistem. Flowchart ini menggambarkan urutan logika dari suatu pemecahan masalah. Berikut adalah flowchart sistem parkir yang diterapkan pada alat arduino tersebut.

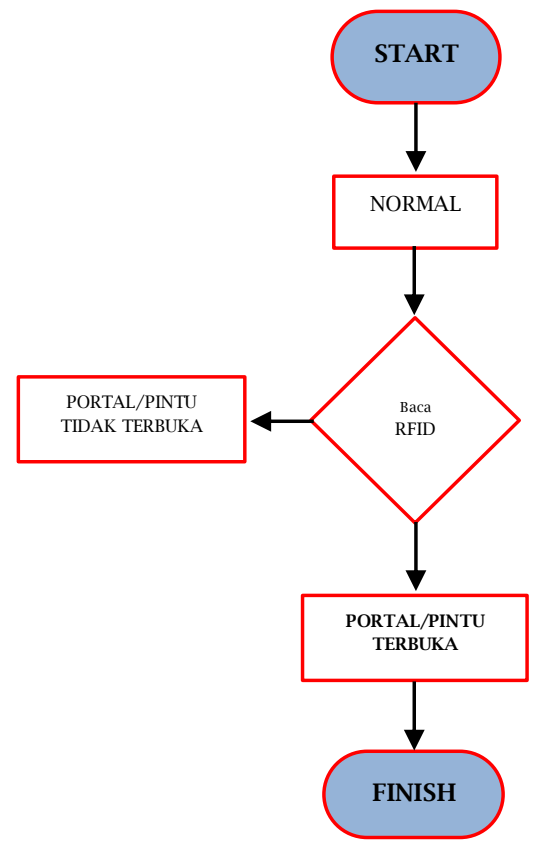

Gambar 2 Flowchart Sistem

Dalam perancangan aplikasi ini, software untuk konsep pembuatan aplikasi sistem parkir, menggunakan visual basic 2010 . Yang mana lembar kerja visual basic 2010 pada gambar berikut : 


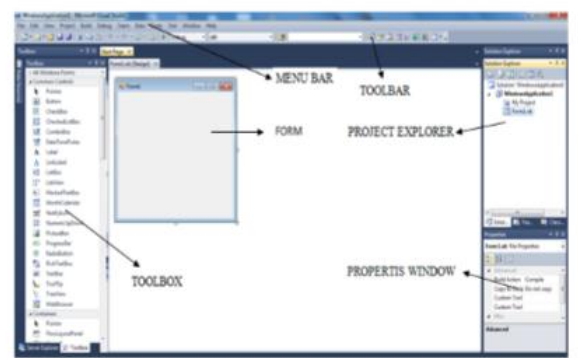

Gambar 3 Rancangan Visual Basic

Dalam merancang database sistem pakir menggunakan Microsoft Acces dan akan dijelaskan pada gambar berikut :
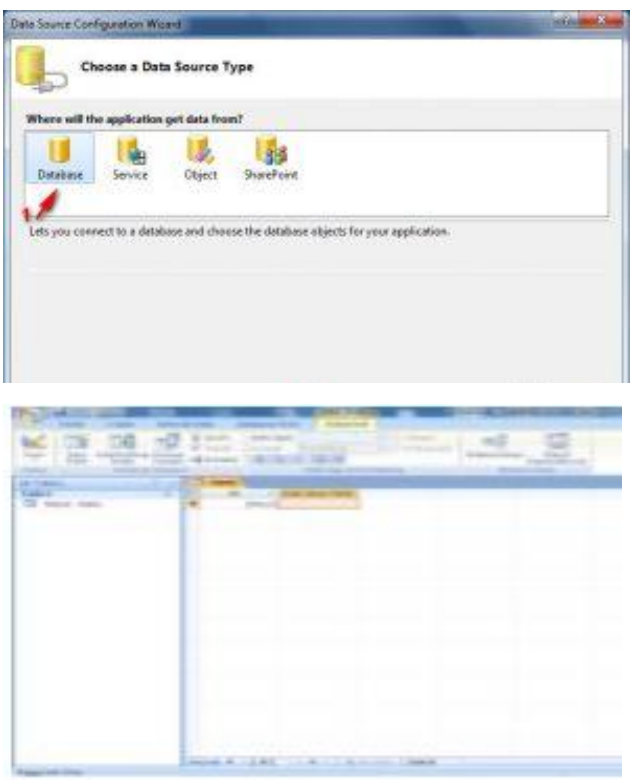

Gambar 4 Perancangan Data Base

Microsoft Access adalah suatu program aplikasi basis data komputer relasional yang digunakan untuk merancang, membuat dan mengolah berbagai jenis data dengan kapasitas yang besar.Aplikasi ini menggunakan mesin basis data Microsoft Jet Database Engine, dan juga menggunakan tampilan grafis yang intuitif sehingga memudahkan pengguna. Versi terakhir adalah Microsoft Office Access 2010 yang termasuk ke dalam Microsoft Office System 2010. Microsoft Access dapat menggunakan data yang disimpan di dalam format Microsoft Access, Microsoft Jet Database Engine, Microsoft SQL Server, Oracle Database, atau semua kontainer basis data yang mendukung standar ODBC. Para pengguna/programmer yang mahir dapat menggunakannya untuk mengembangkan perangkat lunak aplikasi yang kompleks, sementara para programmer yang kurang mahir dapat menggunakannya untuk mengembangkan perangkat lunak aplikasi yang sederhana. Access juga mendukung teknik-teknik pemrograman berorientasi objek, tetapi tidak dapat digolongkan ke dalam perangkat bantu pemrograman berorientasi objek.[6]

\section{Hasil Pembahasan}

Hasil pengujian berdasarkan pengimplementasian dari sistem yang dibuat. Pengujian ini dilakukan untuk mengetahui kemampuan dari sistem dan untuk mengetahui apakah sistem sudah berjalan sesuai dengan baik. Pengujian ini dilakukan pada perangkat keras atau alat. Secara umum, hasil pengujian ini untuk mengetahui apakah alat yang dibuat dapat bekerja sesuai dengan spesifikasi perencanaan yang telah ditentukan. Pengujian dilakukan untuk mengetahui kerja perangkat lunak pada masing-masing blok rangkaian penyusunan sistem, antara lain pengujian LCD , pengujian RFID READER pengujian MOTOR SERVO, pengujian Sensor Ultrasonic, pengujian rangkaian sistem keseluruhan arduino UNO. Data hasil pengujian yang diperoleh nantinya akan dibahas untuk dijadikan dalam pengambilan kesimpulan. Adapun rangkaian keseluruhan dari sistem parkir RFID pada gambar berikut 


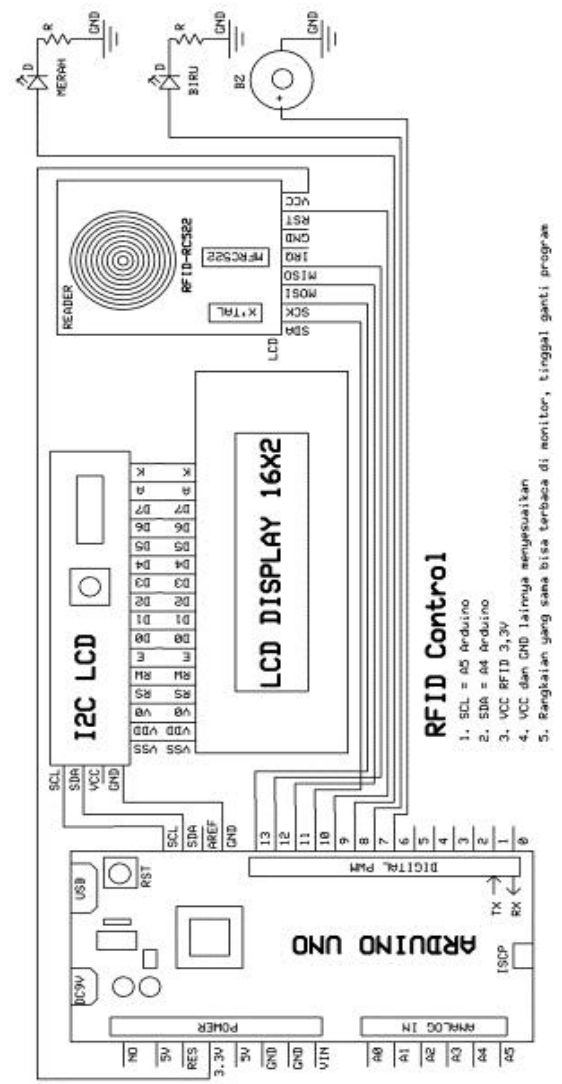

Gambar 5 Sketsa Rangkaian

Pengujian sistem keseluruhan bertujuan untuk mengetahui kinerja dari sistem apakah bekerja dengan baik atau tidak. Pengujian dilakukan dengan membuat miniature simulasi dengan program keseluruhan yang terisi ke dalam arduino UNO, lalu diberikan catu daya ke rangkaian yang terdapat sensor. Pada saat pertama kali dinyalakan semua lampu led di alat dan LCD akan menyala, maka kita harus menunggu sampai semua alat benar-benar siap dan akan tertera di tampilan LCD, setelah itu alat bisa di uji coba. Pada kondisi kendaraan mau masuk, user harus mendekatkan kartu RFID ke RFID Reader. Setelah itu RFID mengecek ke VB.NET apakah Id yang di RFID cocok atau tidak. Ketika data cocok, maka RFID Reader akan memerintahkan Arduino untuk membuka portal dan kendaraan pun masuk. Pada kondisi kendaraan siap keluar, user harus mendekatkan RFID tersebut ke RFID Reader sama seperti penjelasan diatas, jika data cocok maka portal akan terbuka dan dalam hitungan beberapa detik setelah kendaran keluar maka portal akan tertup secara otomatis. Tahap ini akan dilakukan pengujian LCD yang sudah terhubung ke Arduino UNO. Sehingga user bisa melihat nama pemilik kartu RFID yang akan masuk ke lapangan parkir perusahaan. Berikut tampilan gambar hasil pengujian :

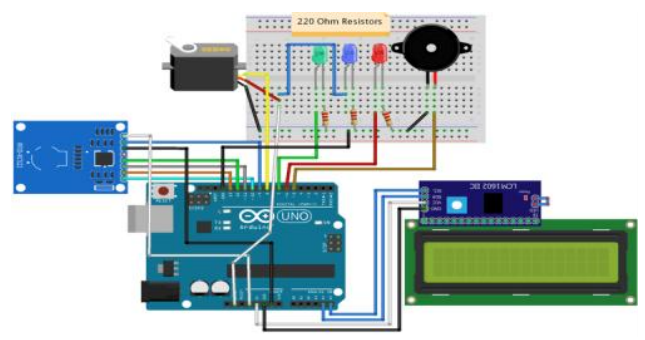

Gambar 6 Hasil Dari Pengujian LCD

Pada gambar 4.2 dijelaskan bahwa gambar diatas adalah pengujian dari rangkaian LCD yang telah dihubungkan ke rangkaian Arduino UNO. Pada tahap ini akan dilakukan pengujian alat yang sudah dihubungkan dengan rangkaian Arduino UNO dan rangkaian LCD. Berikut adalah gambar :

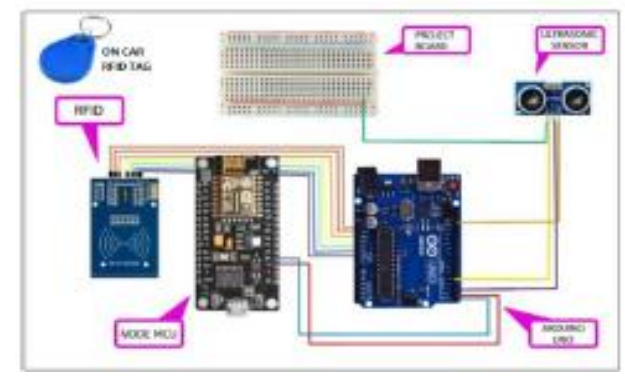

Gambar 7 Hasil Pengujian RFID Reader 
Pada gambar diatas dijelaskan bahwa saat kartu RFID didekatkan ke RFID Reader maka Portal akan terbuka Dan berikut adalah tampilan LCD saat RFID Reader membaca kartu dan akan tertera nama ID kartu :

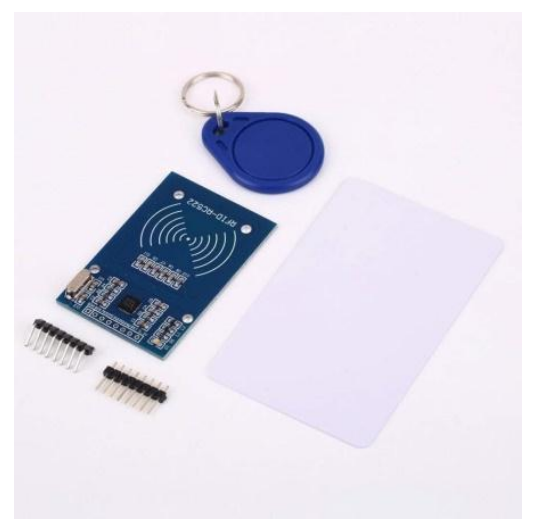

\section{Gambar 8 RFID}

Telah Dibaca RFID Reader Pada gambar diatas dijelaskan bahwa tampilan nama pemilik kartu RFID yang telah dibaca RFID reader dan tertera di tampilan LCD. Pada tahap ini akan dilakukan pengujian dari alat Motor Servo dalam rangkaian sistem parkir RFID. Dalam pengujian ini Motor Servo telah dihubungkan ke Arduino UNO, berikut adalah gambar dari Motor Servo saat tertutup :

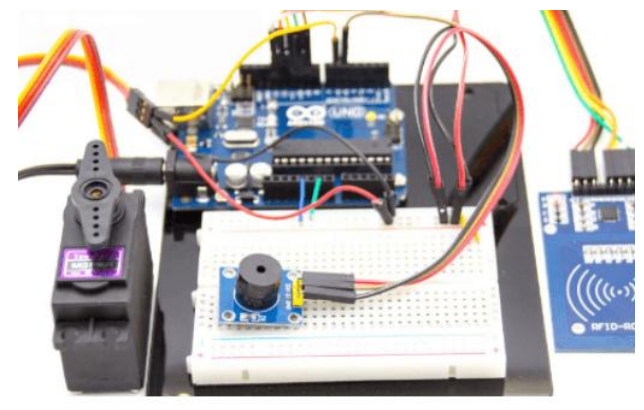

Pada saat kita mau membuka portal yang tertutup, user harus mendekatkan kartu RFID ke RFID Reader dan akan membacanya. Jika data cocok maka portal akan terbuka. Pada keadaan motor servo bergerak membuka portal yang tadinya tertutp. Pada tahap ini akan menguji Sensor Ultrasonic yang telah terhubung ke Arduino UNO yang berfungsi sebagai alat pendeteksi yang akan menutup portal setelah kendaraan telah masuk sepenuhnya.

Pada tahap ini akan dilakukan pengujian perangkat lunak yaitu perangkat lunak yang berfungsi menghubungkan antara hardware dan software. Software VB.Net sebagai software tersebut. Berikut adalah gambar dari tampilan software VB.Net :

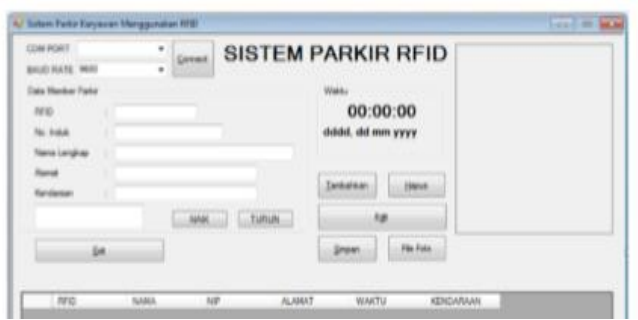

\section{Gambar 12 Tampilan Software Sistem Parkir Sebelum Conect}

Pada gambar 4.8 dijelaskan bahwa software dalam keadaan tidak terkoneksi dengan database dan perangkat sistem parkir. Pada tahap selanjutnya akan ditampilkan hasil pengujian dari perangkat lunak yang telah terkoneksi dengan database dan perangkat sistem parkir, berikut adalah gambarnya :

\begin{tabular}{|c|c|c|}
\hline Validitas & Serial Number & Solenoid \\
\hline Tag Valid & UID B62361 74 & Aktif "HIGH" \\
\hline Tag Tidak Valid & UID 67 I52f00 & Aktif "LOW" \\
\hline Tag RFID & 0006763355 & Tidak merespond \\
\hline
\end{tabular}

Gambar 9 Tampilan Saat Motor Servo Tertutup 
Gambar 13 Tampilan Gambar Saat Data RFID Cocok Dengan DataBase

Pada gambar diatas dijelaskan bahwa saat RFID Reader membaca data dari RFID Card dan apabila ada kecocokan pada data yang tersimpan di database maka software akan menampilkan nama Id Card dan jenis kendaraan nya serta terdapat juga nama Id Card di tampilan LCD yang terdapt pada rangkaian. Pada tahapan ini akan ditampilkan tabel dari database sistem parkir RFID yang menggunakan Microsoft Accsess sebagai sarana penyimpan database sistem

Pada gambar diatas akan dijelaskan bahwasannya tabel diatas data yang benar dalam database, sehingga dapat dipanggil saat dalam proses RFID Reader membaca kartu RFID untuk memasuki lahan perparkiran perusahaan. Berikut adalah kebalikan dari gambar diatas Pada gambar dibawah disini akan ditampilkan salah satu nama dalam database yang tidak sesuai dengan kartu RFID:

\begin{tabular}{|c|c|}
\hline Jarak (Cm) & Terbaca/Tidak Terbaca \\
\hline 0 & Terbaca \\
\hline 1 & Terbaca \\
\hline 2 & Terbaca \\
\hline 3 & Terbaca \\
\hline 4 & Terbaca \\
\hline 5 & Terbaca \\
\hline 6 & Terbaca \\
\hline 7 & Terbaca \\
\hline 8 & Terbaca \\
\hline 9 & Terbaca \\
\hline 10 & Tidak Terbaca \\
\hline
\end{tabular}

Gambar 4.11 Tabel yang tidak terdeteksi/salah

Pada gambar diatas dijelaskan, salah satu nama yang ada didalam tabel database adalah salah atau tidak sesuai dengan data di kartu RFID sehingga saat pemanggilan ID tersebut RFID reader tidak akan mendeteksi keberadaan ID, sehingga portal pada pintu masuk parkir tidak akan terbuka.

\section{KESIMPULAN}

Berikut ini adalah hasil kesimpulan dari alat yang dirancang :

1. Sistem Parkir ini dirancang menggunakan Arduino Uno, RFID Reader, Kartu RFID, LCD, dan Motor Servo. Dan sistem ini dijalankan dengan bahasa pemrograman Visual Basic.

2. Cara kerja dari sistem parkir RFID dengan bahasa pemrograman Visual Basic ini menggunakan kartu RFID, jika Kartu RFID terdeteksi maka portal akan terbuka dan nama pengguna akan muncul ditampilan layar LCD dan jika kartu RFID tidak terdeteksi maka portal tidak akan terbuka dan tampilan dilayar LCD kartu RFID tidak terdeteksi.

\section{DAFTAR PUSTAKA}

[1]2016,PengertianArduino.[Online]Tersedi a:www.ardu ino.cc.[akses 2018]

[2]2018,sensorultrasonik.[Online]Tersediaht tp://kompo

nenelektronika.biz/sensorultrasonik.html.[ak ses2018 ]

[3]2018,RFID.[Online]Tersedia:http://www. RFID.cc.[a kses2018]

[4]2018,MotorServo.[Online]Tersedia:http:// www.moto r servo.cc.[akses2018].

[5] Jogiyanto, 2010, Konsep Dasar Pemograman Bahasa C, Yogyakarta, ANDI PUBLISHER. 